\title{
The Effect of the Type and Composition of the Adhesive on the Physical Properties and the Rate of Combustion Hyacinth Biobriquettes
}

\author{
Lalu Muhamad Alfian Ramdani, Sukainil Ahzan*, Dwi Sabda Budi Prasetya \\ Physics Education, Faculty of Science, Engineering, and Applied Science, Universitas \\ Pendidikan Mandalika, Indonesia \\ *Corresponding Author Email: sukainilahzan@ikipmataram.ac.id
}

\begin{abstract}
Article History
Received: November 2020

Accepted: December 2020

Published: December 2020

Key Words

Attitude; discipline; junior high school students
\end{abstract}

How to cite this article?

\begin{abstract}
This study aimed to identify the effects of variety and composition of the adhesive used to the physical properties and the rate of combustion hyacinth biobriquettes. The physical properties referred to are water content, density and heating value. This research is an experimental study with a literacy study conducted in 3 stages, preparing tools and materials, making biobriquettes, and testing biobriquettes. The main ingredients used in the manufacture of biobriquettes are water hyacinth which is obtained at the Batujai Dam, Central Lombok Regency and the adhesive materials used are wheat flour, tapioca flour and cement. The method used to test the water content and density of the biobriquette was oven, while the calorific value and the rate of combustion were by heating water from the biobriquette combustion. The results showed that the biobriquette water content ranged from $5.138 \%-13.953 \%$, density $0.412 \mathrm{~g} / \mathrm{cm}^{3}-0.513 \mathrm{~g} / \mathrm{cm}^{3}$, calorific value $2984.520 \mathrm{cal}-4476.780 \mathrm{cal}$, and combustion rate $0.029543 \mathrm{~g} / \mathrm{s}-0.042431$ $\mathrm{g} / \mathrm{s}$. Based on the test results, it is known that the addition of adhesive material causes the water content, density, and combustion rate of the biobriquette to increase but the calorific value tends to decrease.
\end{abstract}

Ramdani, L., M., A., Ahzan, S., \& Prasetya, D., S., B. (2020). The Effect of the Type and Composition of the Adhesive on the Physical Properties and the Rate of Combustion Hyacinth Biobriquettes. Lensa: Jurnal Kependidikan Fisika, 8(2), 85-92. doi:https://doi.org/10.33394/j-1kf.v8i2.2786

\section{INTRODUCTION}

The need for subsidized kerosene for tobacco ovens in the NTB region which uses 13,509 oven units reaches 45 million liters (Wijana \& Nurchayati, 2013). The use of this energy must be immediately balanced with the provision of alternative energy in order to overcome the scarcity of petroleum energy sources (Elfiano, et al., 2014). If new energy sources are not found, it is feared that industries that depend on petroleum will experience an energy deficit (Ayuningtias, 2019). The use of wood as a substitute for kerosene for fuel is widely used because the price is relatively cheap and easy to obtain. However, if it is done continuously, it will decrease the potential of wood and cause serious problems for environmental sustainability.

One of the opportunities as an alternative energy source is biomass by turning it into briquettes. Biomass is organic materials derived from plants, animals, aquaculture products and industrial waste (agriculture, plantations, forestry, livestock, and fisheries) (Supriyatno \& Crishna, 2010). Briquettes are solid fuels that are obtained from pressing relatively small or irregular sized materials (Agustina \& Syafrian, 2005). The use of briquettes can save fossil fuel use and can reduce the impact of carbon emissions (Supatata, et al., 2013). 
One of the biomass potentials that can be used as briquettes is water hyacinth. In addition to its very fast growth, water hyacinth also contains many carbon elements, especially cellulose $\left(\mathrm{C}_{6} \mathrm{H}_{10} \mathrm{O}_{5}\right) \mathrm{n}$ (Pangga \& Ahzan, 2019). The cellulose content of dried water hyacinth was quite high, namely $64.51 \%$ (Fachry, et al., 2010). So that water hyacinth is very suitable as a raw material for making briquettes.

The quality of briquettes is not only determined by the raw material, but other factors are the type and composition of the adhesive. The type of adhesive material will have a different effect on the properties and characteristics of the resulting briquettes due to differences in the chemical content of the adhesive (Lestari, et al., 2010). The results of research by Utomo and Primastuti (2013) show that briquettes made from water hyacinth with tapioca starch adhesive are better than wheat flour. In line with Erlinda Ningsih's research, et al (2016) on the effect of the type of adhesive on briquettes, it is stated that the best and meet the SNI among rubber latex, arpus, tapioca starch and sago is tapioca with an adhesive composition of $20 \%$.

Apart from the type of adhesive, the factor of the amount of adhesive can also affect the quality of the briquettes (Permatasari \& Utami, 2015). Based on research conducted by Patabang (2011), it is known that variations in the amount of adhesive affect the quality of the briquettes produced. The results of research by Amin, et al (2017) show that the value of water content increases with increasing the percentage of adhesive on the briquettes. However, the heating value reaches a maximum point for $7 \%$ tapioca adhesive. The results of Hendra's research (2011) show that the best characteristics of water hyacinth briquettes are water hyacinth charcoal briquettes with adhesive at $5 \%$, for mixed briquettes with adhesive by $12.5 \%$, and water hyacinth biobriquettes with adhesive content of $15 \%$.

The data above informs that water hyacinth is a good raw material for briquettes. However, Firdaus (2011) explains that $30 \%$ of the total area of the Batujai Dam in Central Lombok has been covered with water hyacinth. This suggests that its utilization has not been maximized. This inspired me as a researcher to conduct research with the aim of knowing the effect of the type and composition of the adhesive in making water hyacinth biobriquettes on the physical properties and combustion rate of water hyacinth biobriquettes.

\section{METHOD}

This research is an experimental research with literacy study. The research design was carried out in 3 stages, namely.

\section{Stage I: Preparing Tools and Materials}

The tools used are O'hauss balance, briquette molder, calorimeter, sieve shaker, molded cubes, stopwatch, stove oven, thermometer, drum, gas lighter. The material of this research is water hyacinth which is found in Batujai Dam, Praya, Central Lombok Regency. The adhesive consists of wheat flour, tapioca flour and cement.

\section{Stage II: Making Biobriquettes}

Water hyacinth is cleaned and cut into small pieces $( \pm 3-5 \mathrm{~cm})$ and dried under the sun for $5 \times 5$ hours. Furthermore, the charcoal process uses a drum that is burned. The water hyacinth charcoal is then crushed and sieved. Water hyacinth charcoal is added to each adhesive (tapioca, wheat, and cement) which has been prepared at a ratio of $6 \%, 9 \%, 12 \%$, and $15 \%$ of the weight of the biobriquette sample and stirred until it becomes a biobriquette dough. The mixed dough is put into a molder and then dried in a stove oven for \pm 1 hour. 


\section{Stage III: Biobriquette Testing}

The biobriquette was removed and allowed to cool. The resulting biobriquette is then tested for its physical properties including water content, density and calorific value and tested for its combustion rate. The methods used to test the physical properties and combustion rate of the biobriquette are.

\section{Water Content Testing}

The water content of the briquettes was determined by oven method until the mass was constant. Calculation of water content with the formula:

Water content $=\frac{a-b}{a} \times 100 \%$

Information:

$a=$ mass of briquette $(\mathrm{g})$

$b=$ mass of briquette after oven (g)

\section{Density Testing}

The density of the briquettes can be found after the briquette has gone through the stove oven for 1 hour. Calculation of density using the formula:

$\rho=\frac{m}{V}$

Information:

$\rho=\operatorname{density}\left(\mathrm{gram} / \mathrm{cm}^{3}\right)$

$m=$ mass of biobriquette (gram)

$V=$ Biobriquette volume $\left(\mathrm{cm}^{3}\right)$

\section{Calorific Value Testing}

The calorific value is determined by heating the water with the briquette sample for 10 minutes. Then calculate the calorific value with the formula:

$Q=m \times c \times \Delta T$

Information:

$Q=$ Calorific Value (Joule)

$m=$ Mass of water $(\mathrm{kg})$

$c \quad=$ Specific heat of water $(\mathrm{J} / \mathrm{kgK})$

$\Delta T=$ Change in Temperature $(\mathrm{K})$

\section{Combustion Rate Testing}

The rate of combustion can be found by burning the briquette sample until it burns out or until the briquette stops burning. Calculation of the rate of combustion with the formula: Burn Rate $=\frac{m}{t}$

Information:

$m=$ mass of briquette burned (mass of initial briquette - mass of residual briquette) (g) $t=$ burning time (seconds)

\section{RESULTS AND DISCUSSION}

The quality of the briquettes is determined based on testing the physical properties (water content, density and heating value) and the combustion rate of biobriquette. Good briquettes must meet predetermined standards. The results of the research on physical properties and combustion rate of water hyacinth biobriquettes can be seen in Table 1 . 
Table 1. The results of testing the physical properties and the combustion rate of biobriquettes

\begin{tabular}{cccccc}
\hline $\begin{array}{c}\text { Adhesives } \\
\text { Types }\end{array}$ & $\begin{array}{c}\text { Adhesives } \\
\text { Composition }\end{array}$ & $\begin{array}{c}\text { Water } \\
\text { Content } \\
(\%)\end{array}$ & $\begin{array}{c}\text { Density } \\
\left(\mathrm{g} / \mathrm{cm}^{3}\right)\end{array}$ & $\begin{array}{c}\text { Calorific } \\
\text { Value } \\
(\mathrm{Cal})\end{array}$ & $\begin{array}{c}\text { Combustion } \\
\text { Rate } \\
(\mathrm{g} / \mathrm{s})\end{array}$ \\
\hline $\begin{array}{c}\text { Tapioca } \\
\text { flour }\end{array}$ & $6 \%$ & 5.63 & 0.412 & 4178.328 & $3.06 \times 10^{-2}$ \\
& $9 \%$ & 6.78 & 0.425 & 4476.780 & $3.29 \times 10^{-2}$ \\
& $12 \%$ & 7.41 & 0.454 & 3879.876 & $3.54 \times 10^{-2}$ \\
Wheat & $6 \%$ & 12.95 & 0.482 & 3282.972 & $4.14 \times 10^{-2}$ \\
flour & $9 \%$ & 5.35 & 0.418 & 4178.328 & $3.54 \times 10^{-2}$ \\
& $12 \%$ & 8.35 & 0.435 & 3879.876 & $3.80 \times 10^{-2}$ \\
& $15 \%$ & 13.95 & 0.450 & 3581.424 & $4.12 \times 10^{-2}$ \\
Cement & $6 \%$ & 5.14 & 0.436 & 4178.328 & $2.95 \times 10^{-2}$ \\
& $9 \%$ & 7.82 & 0.470 & 4178.328 & $3.01 \times 10^{-2}$ \\
& $12 \%$ & 9.46 & 0.490 & 3879.876 & $3.27 \times 10^{-2}$ \\
& $15 \%$ & 13.84 & 0.513 & 3282.972 & $3.59 \times 10^{-2}$ \\
\hline
\end{tabular}

Based on Table 1 above, it can be explained in detail about the effect of the type and composition of the adhesive on the physical properties and combustion rate of the biobriquette as follows:

\section{Water Content}

The water content is the amount of water present in the briquette after the oven process. The complete water content of the biobriquette produced can be seen in Figure 2.

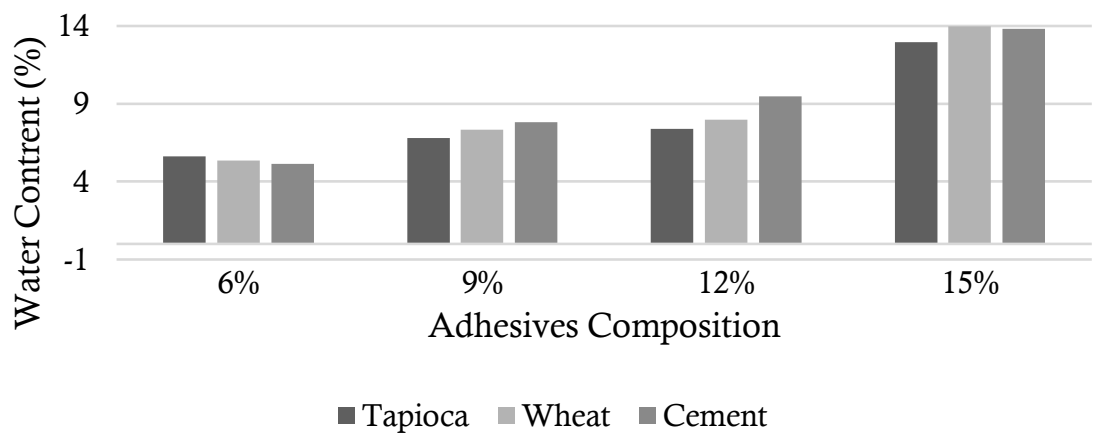

Figure 2. Water Content Percentage Graph

Based on Figure 2 it can be seen that the water content in the biobriquette ranges from $5.138 \%-13.953 \%$. The biobriquette which has the lowest percentage of water content is the biobriquette with cement adhesive at a composition of $6 \%$. Meanwhile, the highest water content in biobriquette with flour adhesive is $15 \%$. The percentage of good water content according to SNI-01-6235-2000 does not exceed 8\%. The resulting water content of the biobriquette that fulfills the characteristics according to the SNI above is biobriquette with an adhesive composition of $6 \%$ and $9 \%$ for each type of adhesive, and a composition of $12 \%$ for tapioca adhesive.

The data above informs that the water content of the briquettes is directly proportional to the adhesive composition used. This is in line with research by Ristianingsih, et al (2015) which states that the water content of briquettes is higher along with the more adhesive composition used. Maryono, et al (2013) explained that the 
addition of the adhesive composition causes the briquette to have a higher density so that the briquette pores will be smaller. Karim, et al (2016) added that the small porous briquettes cause the water trapped inside it is difficult to evaporate during the oven process.

Apart from the adhesive composition, another factor that affects the water content in the briquettes is the type of adhesive used. This is due to the chemical substances contained in different adhesive materials. The best adhesive material is the one with the least water content, namely cement with a composition of $6 \%$. Cement is a hydraulic adhesive that hardens when mixed with water. In addition, this adhesive is stronger than organic adhesives such as tapioca and wheat, but the costs incurred are higher and produce more ash (Miskah, et al, 2016).

\section{Density}

The density of briquettes is the ratio between the mass and the volume of briquettes. The complete density of the resulting biobriquette can be seen in Figure 3 .

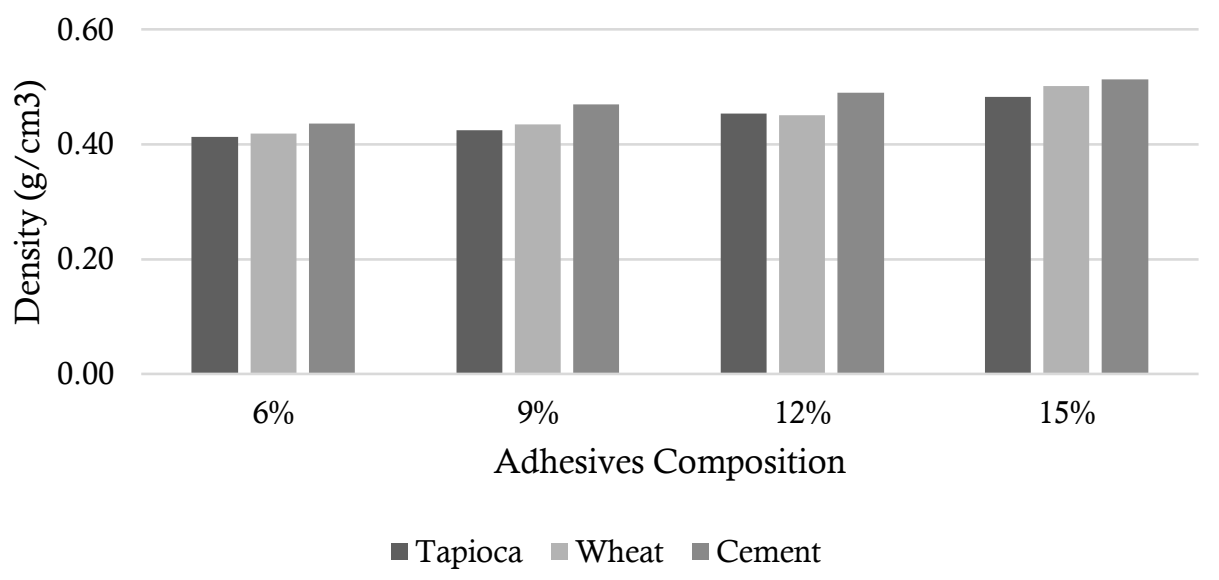

Figure 3. Biobriquette Density Graph

Based on Figure 3 above, it can be seen that the type and composition of the adhesive material has a different effect on the density of the biobriquette. The resulting biobriquette density ranged from $0.412 \mathrm{~g} / \mathrm{cm}^{3}-0.513 \mathrm{~g} / \mathrm{cm}^{3}$. Biobriquette which has the lowest density is biobriquette with tapioca adhesive at $6 \%$ composition. Meanwhile, the highest density of cement adhesive is at the composition of $15 \%$. The resulting biobriquette density has met the density standard for commercial briquettes, which is above $0.4 \mathrm{~g} / \mathrm{cm}^{3}$. The resulting density value of the biobriquette was higher as the composition of the adhesive was used. This is due to the higher water content which causes the mass of the biobriquette to be bigger with the volume of biobriquette that is kept constant. This is in line with the research of Iriany, et al. (2016) which states that the higher the addition of adhesive causes the briquette density to be higher because the adhesive will enter the briquette pores. Fatmawati, et al, (2014) explained that the lower the density of a briquette, the easier it is to burn, but it is brittle and easily destroyed due to too many air voids. Meanwhile, briquettes with high density will increase the calorific value, but briquettes are difficult to burn (Afriyanto, 2011).

\section{Calorific Value}

The calorific or heating value is the amount of heat energy released or generated by a fuel through the combustion reaction of the fuel. The calorific value is the main parameter in determining the quality of the biobriquette produced. The higher the calorific value, the better the briquette quality. The complete calorific value of the resulting biobriquette can be seen in Figure 4. 


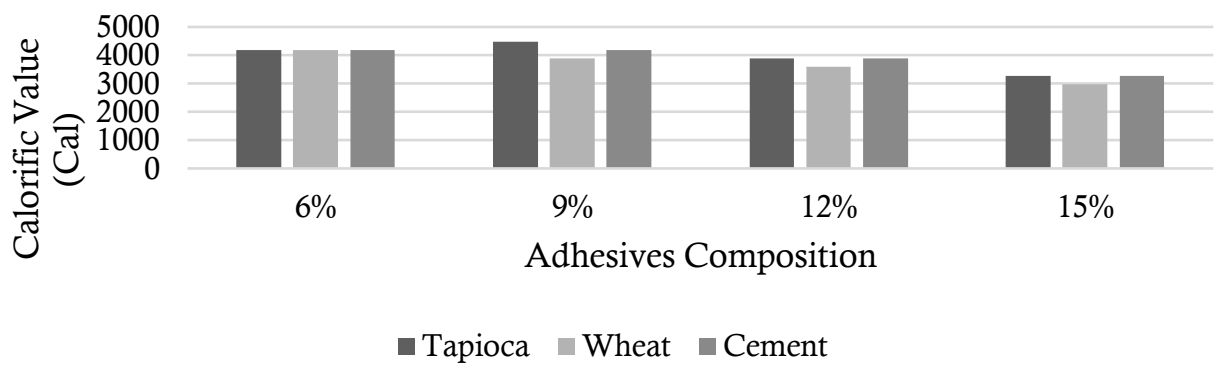

Figure 4. Biobriquette Calorific Value Graph

Based on Figure 4 above, it can be seen that the type and composition of the adhesive has a different effect on the calorific value of the biobriquette produced. The calorific value of biobriquettes ranges from 2984.520 calories -4476.780 calories. The biobriquette which has the lowest calorific value is the biobriquette with flour adhesive at a composition of $15 \%$. Meanwhile, the highest calorific value in biobriquette with tapioca adhesive is at $9 \%$ composition. This is because the calorific value is influenced by the water content of the briquettes. The higher the amount of briquette water content, the lower the calorific value produced. This is because the calorific value produced by the briquettes is first used to evaporate the water trapped in the briquette before producing heat which is used as combustion heat (Ismayana \& Afriyanto, 2012).

\section{Combustion Rate}

The rate of combustion is the speed at which the briquettes burn out. The complete combustion rate value of the resulting biobriquette can be seen in Figure 5 .

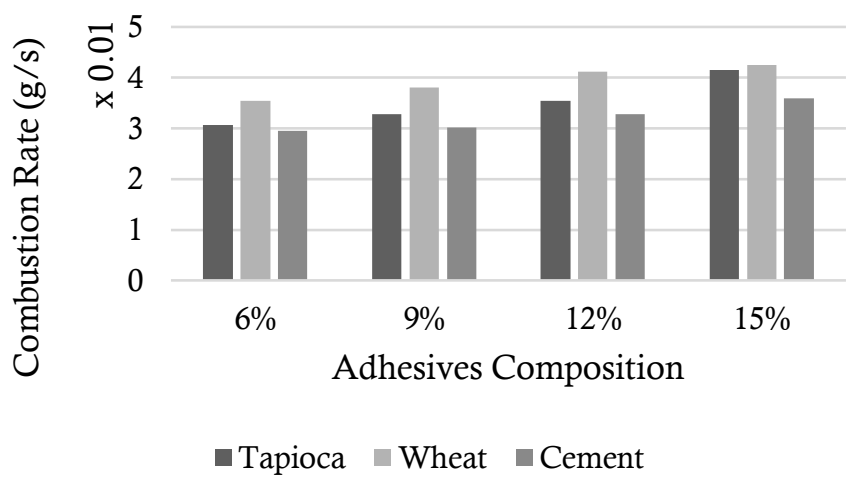

Figure 5. Biobriquette Combustion Rate Graph

Based on Figure 5 above, it can be seen that the type and composition of the adhesive material has a different effect on the combustion rate of the resulting biobriquette. The combustion rate of water hyacinth biobriquettes ranged from $0.029543 \mathrm{~g} / \mathrm{s}-0.042431 \mathrm{~g} / \mathrm{s}$. Biobriquette with the lowest combustion rate is biobriquette with cement adhesive at a composition of $6 \%$. While the biobriquette with the highest combustion rate was the biobriquette with wheat flour adhesive at a composition of $15 \%$. The burning rate of the biobriquette is directly proportional to the adhesive composition used. This is in line with the results of Hendra's research (2011) that the combustion rate of biobriquettes is higher as the more adhesive composition is used. The higher the combustion rate of the briquettes, the faster the briquettes will burn out. This is because the combustion which should be the briquette calorific value is used to evaporate the moisture content of the briquette. The more the adhesive composition, the higher the biobriquette water content. As a result, more water will be evaporated during the combustion process. This causes the 
briquettes to lose a lot of mass in a short time which results in the briquettes having a higher combustion rate.

\section{CONSLUSSION}

The results showed that the lowest water content value was owned by cement adhesive biobriquette $6 \%$ with a value of $5.138 \%$, the highest was wheat flour adhesive biobriquette $15 \%$ with a value of $13.953 \%$. The lowest density was owned by $6 \%$ tapioca adhesive biobriquette with a value of $0.412 \mathrm{~g} / \mathrm{cm}^{3}$, the highest was in the cement adhesive biobriquette $15 \%$ with a value of $0.513 \mathrm{~g} / \mathrm{cm}^{3}$. The lowest calorific value is owned by wheat flour adhesive biobriquette $15 \%$ with a value of 2984,520 calories, the highest is tapioca adhesive biobriquette $9 \%$ with a value of 4476,780 calories. The lowest burning rate was owned by $6 \%$ cement adhesive biobriquette with a value of $0.029543 \mathrm{~g} / \mathrm{s}$, the highest was for $15 \%$ wheat flour adhesive biobriquette with a value of $0.042431 \mathrm{~g} / \mathrm{s}$. The addition of adhesive causes the water content, density and combustion rate of the biobriquette to increase but the calorific value tends to decrease.

\section{RECOMMENTATION}

Suggestions that can be recommended from this research are that in the preparation, manufacturing and testing stages of biobriquettes, it is recommended to be carried out simultaneously and obtain the same treatment to minimize the impact of environmental factors in the form of temperature and humidity which cannot be ascertained to be always the same at the time of research because it utilizes sunlight. In addition, there is a need for further study of water hyacinth biobriquettes with different variables to produce a value that is in accordance with the Indonesian National Standard (SNI).

\section{ACKNOWLEDGMENTS}

This research received no specific grant from any funding agency in the public, commercial, or not for profit sectors.

\section{REFERENCES}

Afriyanto, M. R. (2011). Pengaruh Jenis dan Kadar Bahan Perekat pada Pembuatan Briket Blotong sebagai Bahan Bakar Alternatif. S1 Skripsi. Institut Pertanian Bogor.

Agustina, S. E. \& Syafrian A. (2005). Mesin Pengempa Briket Limbah Biomassa, Salah Satu Solusi Penyediaan Bahan Bakar Pengganti BBM untuk Rumah Tangga dan Industri Kecil. dalam Seminar Nasional dan Kongres Perteta. Bandung, Indonesia.

Amin, A. Z., Pramono, Sunyoto. (2017). Pengaruh Variasi Jumlah Perekat Tepung Tapioka Terhadap Karakteristik Briket Arang Tempurung Kelapa. Jurnal Sainteknol. 15(2): 111-118.

Ayuningtias, A. W. (2019). Uji Karakteristik Biobriket dari Tanaman Eceng Gondok dan Sekam Padi dengan Variasi dan Perekat Berbeda. S1 Skripsi. Universitas Muhammadiyah Surakarta.

Elfiano, E., Subekti, P., Sadil, A. (2014). Analisa Proksimat dan Nilai Kalor Pada Briket Bioarang Limbah Ampas Tebu dan Arang Kayu. Jurnal Aptek. 6(1): 57-64.

Fachry, A. R., Sari, T. I., Dipura, A. Y., Najamudin, J. (2010). Mencari Suhu Optimal Proses Karbonisasi dan Pengaruh Campuran Batubara terhadap Kualitas Briket Eceng Gondok. Jurnal Teknik Kimia. 17(2), April 2010. 
Fatmawati, D. \& Adiwibowo, P. H. (2014). Pembuatan Biobriket dari Campuran Eceng Gondok dan Tempurung Kelapa dengan Perekat Tetes Tebu. Jurnal JTM. 3(2): 315322.

Firdaus, A. (2011). Dampak Pencemaran Lingkungan Kota Praya Terhadap Kualitas Air Waduk Batujai. Buletin Geologi Tata Lingkungan. 21(2): 69-82.

Hendra, D. (2011). Pemanfaatan Eceng Eondok (Eichornia crassipes) untuk Bahan Baku Briket sebagai Bahan Bakar Alternatif. Jurnal Penelitian Hasil Hutan. 29(2): 189-210.

Iriany, Meliza, Abednego, F., Sibarani, S., Irvan. (2016). Pengaruh Perbandingan Massa Eceng Gondok dan Tempurung Kelapa serta Kadar Perekat Tapioka Terhadap Karakteristik Briket. Jurnal Teknik Kimia. 5(1): 20-26

Ismayana, A. \& Afriyanto, M. R. (2012). Pengaruh Jenis dan Kadar Bahan Perekat pada Pembuatan Briket Blotong sebagai Bahan Bakar Alternatif. Jurnal Teknologi Industri Pertanian. 21(3): 186-193.

Karim, M. A., Ariyanto, E., Firmansyah, A. (2014). Biobriket Enceng Gondok (Eichhornia Crassipes) Sebagai Bahan Bakar Energi Terbarukan. Reaktor. 15(1): 5963.

Lestari, L., Aripin., Yanti., Zainuddin., Sukmawati., Marliani. (2010). Analisis Kualitas Briket Arang Tongkol Jagung yang Menggunakan Bahan Perekat Sagu dan Kanji. Jurnal Aplikasi Fisika. 6(2): 93-96.

Maryono, Sudding, Rahmawati. (2013). Pembuatan dan Analisis Mutu Briket Arang Tempurung Kelapa Ditinjau dari Kadar Kanji. Jurnal Chemika. 14(1): 74-83.

Miskah, S., Lestari, A., Damayanti, E. P. (2016). Pengaruh Variasi Jumlah Campuran Perekat Tapioka dan Semen Terhadap Pembuatan Biobriket Ampas Tebu. Jurnal Teknik Kimia. 22(4): 11-18.

Ningsih, E., Mirzayanti, Y. W., Himawan, H. S., Indriani, H. M. (2016). Pengaruh Jenis Perekat Pada Briket Dari Kulit Buah Bintaro Terhadap Waktu Bakar. dalam Seminar Nasional Teknik Kimia "Kejuangan". Yogyakarta, Indonesia.

Pangga, D. \& Ahzan, S. (2019). Pengembangan Eceng Gondok sebagai Bahan Dasar Pembuatan Briket Sumber Energi Alternatif. dalam Seminar Nasional. Mataram, Indonesia: FPMIPA, IKIP Mataram.

Patabang, D. (2011). Studi Karakteristik Termal Briket Arang Kulit Buah Kakao. Jurnal Mekanikal, 2(1): 23-31.

Permatasari, I. Y. \& Utami, D. (2015). Pembuatan dan Karakteristik Briket Arang dari Limbah Tempurung Kemiri (Aleurites Moluccana) dengan Menggunakan Variasi Jenis Bahan Perekat dan Jumlah Bahan Perekat. dalam Seminar Nasional Kimia, (pp 59-69), Yogyakarta, Indonesia: Jurusan Pendidikan Kimia, FMIPA UNY.

Ristianingsih, Y., Ulfa, A., Syafitri, R. K. S. (2015). Pengaruh Suhu dan Konsentrasi Perekat Terhadap Karakteristik Briket Bioarang Berbahan Dasar Baku Tandan Kosong Kelapa Sawit dengan Proses Pirolisis. Jurnal Konversi. 4(2): 16-22.

Supatata, N., Buates, J., Hariyanont, P. (2013). Characterization of Fuel Briquettes Made from Sewage Sludge Mixed with Water Hyacinth and Sewage Sludge Mixed with Sedge. International Journal of Environmental Science and Development. 4(2): 179-181.

Supriyatno \& Crishna B. M. (2010). Studi Kasus Energi Alternatif Briket Sampah Lingkungan Kampus POLBAN Bandung. dalam Prosiding Seminar Nasional Teknik Kimia "Kejuangan". Yogyakarta, Indonesia: UMY.

Wijana, M. \& Nurchayati. (2013). Desain Tungku Briket Biomassa System Kontinyu Sebagai Teknologi Pemanfaatan Energi Alternatif Pengganti Bahan Bakar Terpakai Pada Oven Tembakau Di Masyarakat Pedesaan. Jurnal Teknik Mesin Universitas Mataram. 3(1): 60-66. 